\title{
Surrealisme, lekenhet og det uhyggelige i Ellen Einans lyrikk
}

\section{Surrealism, Playfulness and the Uncanny in the Poetry of Ellen Einan}

\section{Eva Pitronová}

\begin{abstract}
This paper deals with the poetic oeuvre of one of the most enigmatic Norwegian poets, Ellen Einan. Altogether, she published 14 poetry collections between 1978 and 2009. All of them are characterized by an automatic writing technique, specific metaphorical images and complicated language constructions. In this article, which is based on my diploma thesis, I focus on modernist and surrealist elements in the work of Einan. These are mainly manifested in the composition of the text in regards to its obvious incoherence, in the way the author composes new words, but also in motives such as connection between sleep, game and death. In the last section, I point to Einan's elaboration of the uncanny and the disturbing, convulsive beauty. In this sense, she can be compared to female surrealist poets.
\end{abstract}

\section{Keywords}

Ellen Einan, Norwegian poetry, modernism, surrealism, metaphor, convulsive beauty 


\section{Eksepsjonell debut}

«Ho liknar ingen andre» sier Vigdis Ystad i den aller nyeste artikkelskissen viet til den norske lyrikeren Ellen Einan. Ystad tilføyer at Einan er en av «dei verkeleg store og djupt originale samtidslyrikarane». ${ }^{1}$ Likevel er Einans dikterpersonlighet ganske ukjent for samtidige lesere - både i Norge og utlandet. Ellen Einan, en av de mest fantasifulle og innovative norske poetene, hadde en framtredende plass i norsk poesi på 1980-tallet og også tiåret etterpå, men kom mer i bakgrunnen etter hvert. I litteraturvitenskapelig sammenheng har interessen for hennes diktning vært liten. ${ }^{2}$ Det er bare umiddelbare følelser og fornemmelser ved diktlesningen vi skulle ta i betrakting. Denne artikkelen er oppstått i tilknytning til min masteroppgave « $\AA$ møte de indre roms ansikt. Ellen Einans lyrikk» ved Masaryk universitet. I masteroppgaven har jeg anvendt surrealistisk og feministisk lesning av Einans dikt og har foreslått noen konkrete tolkningsmuligheter. Denne artikkelen kan mest forstås som en innføringsstudie enn et sammendrag av hele masteroppgaven. Siden prosjektet mitt er relativt omfattende og utdypende, vil jeg her begrense mitt fokus til det surrealistiske aspektet ved Einans diktning. For å gjøre utvalget av diktene mer tydelig, fokuserer jeg hovedsakelig på diktene med valmuesymbolikken og forveksling mellom søvn og død. Men innledningsvis vil jeg sette søkelyset på Einans livsverk og hennes forfatterstrategier.

«Mørk og merkelig debutant», skrev Jan Erik Vold om Einan da hennes første diktsamling ble publisert i $1982 .{ }^{3}$ Einan kom som en merkelig gammel dame og satte norsk lyrikk på hodet. Hun var en dikter som i liten grad hadde vært litterært skolert, men med utrettelig vilje til å gi stemme til ordene fra det innerste. I tillegg er hennes livshistorie like oppsiktsvekkende som hennes merkelige poesi. Einan ble født i Svolvær, Lofoten i 1931 og bodde der hele sitt liv fram til hun døde i 2013. Hun var trebarnsmor og jobbet på gamlehjem og i hjemmesykepleien. Siden ungdommen hadde hun utviklet en interesse for psykisk automatisme som først resulterte i tegneproduksjon og etter hvert i diktekunst. Hennes biografi bærer derfor en aura av noe særegent og egenartet, men samtidig gir den få svar på hvorfor og på hvilken måte Einan konstruerte sine dikt. Enda vanskeligere er å finne konkrete forbilder hun kunne føle seg inspirert av. Man kan kalle henne for en autodidakt, men samtidig peker mye mot at før hennes egen dikteriske suksess hadde hun ikke noen interesse i skjønnlitteratur. Hennes liv bærer ingen preg av kunstneriske ambisjoner, hun jobbet atskilt fra litteraturmiljøet i Oslo og andre større byer. Hun var heller ikke en stor leser og interesserte seg for spiritistisk og religiøs litteratur. Dypere kunnskaper om poesi kommer hovedsakelig som følge av hennes egen produksjon.

Einans første diktsamling kom ut i 1978 da hun var 45. Men samlingen Valmuesanger fra solhuset kan vi neppe regne som en vanlig debut. Boka var et stensiltrykk som ble

1 Ystad, Vigdis: Diktet. Dag og tid. 12. 1. 2018.

2 Unntak er tre drøftende artikler skrevet av H. Gujord (1996) og Ch. Armstrong (1997, 2017), se bibliogra-

fi.

3 Vold, Jan Erik: Poetisk praksis 1975-1990. Oslo 1990, S. 158. 
trykket av dikterens eldste sønn Bjørn og inneholdt 48 dikt. Ifølge Vold sendte Einan dette heftet til tre berømte norske diktere: Georg Johannesen, Olav H. Hauge og Jan Erik Vold. Mens den første anbefalte henne å «brenne» alt, var de to siste svarene tydelig positive og oppmuntrende. Vold erklærer seg selv som den personen som foreslo henne å ta kontakt med et forlag. ${ }^{4}$ Siden denne amatørmessige debuten har Einan utgitt andre 13 diktsamlinger og dessuten 18 dikt som ble publisert under tittelen «Nye dikt» i tidsskriftet POESI i 1984. Etter den første «prøvesamlingen» kom Einan med sin egentlige debut på et offentlig forlag i 1982. Den gode engsøster ble publisert av Solum Forlag. Der har hun utgitt hele sin dikteriske produksjon bortsett fra den første, private utgaven og en samling fra 1984 utgitt på Gyldendal Norsk Forlag. Einans komplette produksjon består av 1042 dikt med en stort sett konsentrert form. Diktsamlingene hennes er følgende: Valmuesanger fra solhuset (1978), Den gode engsøster (1982), Muldsøstre (1983), Jorden har hvisket (1984), Søster Natt (1985), Nattbarn (1986), Sene rop mellom bronsebergene (1987), Hestene våker i duggtoneengen (1989), Døgnfargene er mørke (1991), De syv nattstegene (1992), Jade for min engel (1994), Innenfor og utenfor er ett (1999), Dagen fär min uro (2004) og Noen venter på bud (2009).

\section{«Jeg bruker dikt for å leve i døden som en levende»}

Med disse ordene karakteriserer Einan sin egen diktning i diktet «Bruken av dikt» fra 1994 (364). Man ville forvente det aller motsatte - at diktene skulle virke som et hjelpemiddel for å kommunisere med de døde, men Einan gjør oss tvilende og undergraver vår stereotypiske forståelse av livkretsløp. Forvekslingen mellom livet og døden kjennetegner stemningen $\mathrm{i}$ alle diktsamlingene, men i det sene forfatterskapet er dette emnet enda mer aksentuert. På dette tidspunktet, da Jade for min engel er utgitt, har hennes poetiske vitnesbyrd kulminert og oppnådd sin imaginære topp. Hennes mystiske vokabular og innovative ordbilder får litt løsere form og også deres indre kraft er ikke så gripende. Etter ni diktsamlinger som ble mottatt ytterst positivt, kommer det plutselig den første kritiske anmeldelsen og poeten begynner å vurdere sin skriving og forfatterskap. ${ }^{5}$ Ikke bare ut av dette kan man dele Einans produksjon i flere faser.

Den første private diktsamlingen Valmuesanger fra solhuset står litt for seg, utgitt et par år før den offentlige debuten. Likevel er den ganske bestemmende, og her bygges og konstrueres egenskaper som snart blir karakteristiske for hele forfatterskapet. Den mest produktive periode var mellom 1982 til 1994 da Einan ga ut ti diktsamlinger. Disse kan vi stort sett dele i to grupper - mellom 1982 og 1987; og mellom 1989 og 1994. ${ }^{6}$ De seks første samlingene kommer ut hvert år på rad og skaper en fantasifull og indre helhet. Der viser Einans merkelige språkevne seg på sitt beste. De fire neste samlingene

4 Vold, Jan Erik: En stripe av marmor. In: Einan, Ellen: Samlede dikt. Oslo 2011, S. 476.

5 Her er det snakk om Eilif Straumes anmeldelse I Ellen Einans forunderlige have. In: Aftenposten, 26. 1. 1995.

6 Her referer jeg til Øystein Rottem som påpeker en indre innholdsmessig utvikling mellom enkelte diktsamlinger. Rottem, Øystein: Etterkrigslitteraturen. Bind 3: Vår egen tid 1980-1998. Oslo 1998, S. 564. 
er ikke lenger så skarpe i språkeksperimenter, og samtidig kommer flere bibelallusjoner til uttrykk. Etterpå kommer en relativt lang taushet og de tre siste samlingene med 5 års tidsavstand mellom hver. Disse tre er merkbart annerledes. Charles Armstrong knytter dem til en såkalt sen-stil-fenomen ${ }^{7}$ der forfatterskapet renses for andre billedlige lag enn det vesentligste - den kommende døden. I disse samlingene nærmer døden seg som en god og velkjent venn. For meg spiller det tidlige verket (mellom årene 1984-87) den viktigste rollen i analysen, når det febrilske tempoet sammen med vanskelige og ubegripelige metaforbilder overrumpler våre sanser og leder oss inn i et lukket univers.

I sine dikt er Einan hovedsakelig opptatt av natur og sjeleliv. Vold og andre antar at hennes nære forhold til naturen må ha vært en av hovedkildene til hennes skaperkraft. Likevel er naturbeskrivelsene av en helt annen art enn for eksempel de taktile og samtidig skarpe metaforene til Gunvor Hofmo. Einans bilder er derimot mer diffuse, mørke og uten klare konturer. Diktene hennes er smidd av naturens hemmelige krefter, men hennes natur er samtidig helst privat, arkaisk og full av arketypiske symboler for fruktbarhet, død og naturkretsløp. Hun går slettes ikke tett på det synlige og nærværende. Hun lever i sine indre hager med en sverm av åndelige søstre og en mystisk morsfigur. Dessuten er Einan veldig sjenert og nekter å innrømme forfatterskapet sitt for seg selv. Hun har sagt slike ting som dette: «Jeg bare setter meg ned og så kommer det til meg. Det er et jeg inne i meg som dikterer det jeg skal skrive og jeg noterer hele diktet ned før jeg leser det gjennom.» ${ }^{8}$ Hun virker prisgitt og forsvarsløs mot sin egen uforklarlige skaperkraft. I et intervju fra Samtiden antyder hun at det kanskje var berøringen av rognetreet med sine magiske egenskaper som hadde utløst all denne automatskriften. ${ }^{9}$ Det finnes ikke mange publiserte vitnesbyrd om Einans spiritistiske aktiviteter til rådighet, men Einans evne til å «kommunisere med ånder» er her og der nevnt. ${ }^{10}$ Egentlig er de beste bevisene på denne aktiviteten selve diktene. Først eksperimenterte Einan med automatisk tegning. Hun hadde tegnet mysteriøse menneskelige og dyreaktige figurer med ett penseldrag i mange år før hun begynte å skrive. ${ }^{11}$ Einan hadde bare liten og stort sett teoretisk kjennskap til Bretons surrealisme og hans teorier om psykisk automatisme, andre impulser fant hun hos Swedenborg, C.G. Jung og Stanislav Grof. Vold skriver at «diktskrivingen overrumplet henne» og kom plutselig og virket insisterende og nesten påtrengende. ${ }^{12}$

7 Begrepet «sen stil» er tatt fra Edward Said, for mer se: Armstrong, Charles: «Jeg er en hugget gren.» Fra tap til fravær i Ellen Einans forfatterskap. In: Christine Hamm [et al.]: Lidelsens estetikk. Sår, sorg og smerte i litteratur, film og medier. Bergen 2017, S. 38-50.

$8 \quad$ Lyrikeren Ellen Einan priset. In: Aftenposten, 22. 8. 2002.

9 Vold, Jan Erik: Jeg som bare lener blyanten sånn passe mot papiret og la den fly... In: Samtiden nr. 1 1985, S. $65-72$.

10 Einan har bidratt med to fortellinger «Kontakt med dame fra den andre siden» og «Samtaler med tre og steiner» i samlingene av nordnorske sagn Gandere og hjelpere i nordområdene og Det usynlige nord samlet av Roald Larsen (og Lev Levit), utgitt av Arktisk Forlag (2011, 2012).

11 Hvor lenge før diktningen det var, er uklart, men noen uttalelser tyder på at Einan var trettiåring da hun begynte å tegne. F. eks Johansen sier at hun tegnet siden 1970-tallet. Johansen, Hugo: En gåtefull verden. In: Lofotposten, 15. 5. 2012, S. 12.

12 Vold, [op. cit. 4], S. 475. 
Einan hevdet til og med at hun ikke var ansvarlig for sine dikt, men stort sett likte hun å kommentere dem: «Jeg blir jo egentlig ikke inspirert av noe. Men hvert dikt starter med en tegning som gjerne kan bestå av trær, hester eller et ansikt. Alle mine dikt har et navn.» ${ }^{13}$ Hun trodde på den kollektive underbevisstheten og syntes at dette kunne belyse hvor skaperkraften kom fra. Siden Jorden har visket ble publisert, skrev Einan mange av sine dikt som фnskedikt, dvs. at hun ved hjelp av en diktningsprosess som lignet på en samtale med ånder, fikk vite noe ønskelig om personer hun viet dikt til med tittelen «hos...». ${ }^{14}$ Denne tittelen er samtidig ikke en del av diktene. Men vi finner mange motsigelser i hennes utsagn om hvordan diktene blir til. Det eneste denne teknikken viser absolutt klart, er at ord og bilde - dikt og tegning i stor grad er sammenkoblet. Det er også verdt å nevne at Einan skrev dikt i mye større antall enn lesere kunne få lest. Forlagene publiserte hver gang bare et utvalg av diktene som hadde kommet til forlagshuset i noen kilo papir! Da er det ikke noe rart at Terje Dragseth sier litt som spøk at Einan er «et vidunderlig supplement til norsk forlagskonsulentpoesi». ${ }^{15}$

Ved siden av en uvanlig skriveteknikk, er det også den motiviske verden som er bemerkelsesverdig. I sentrum av alle diktene står en ukjent Jeg-personlighet. For eksempel danner «Jeg» det første ordet i nesten halvparten av dikttitlene. ${ }^{16}$ Vi ser på verden omkring gjennom Jegets blikk, selv om Jegets identifikasjon er vanskelig. Dette er forårsaket av at Jegets eksistens ikke er strengt begrenset. Vi vet ikke engang om det er det samme Jeget eller om de er flere. I utgangspunktet skal vi se på Jegets stemme som fragmentert, men identisk i alle dikteriske utsagn. Dette Jeget erfarer og formidler opplevelser som er typiske for kvinner, kaller seg selv for datter dørselgerske eller bruker andre beskrivelser typiske for kvinner, derfor kan vi våge å snakke om det kvinnelige Jeget. I tillegg til Jeget dukker det stadig opp noen flere merkelige skikkelser. Mor er en framtredende figur som danner et slags motstykke til Jeget. Hun dukker ofte opp sammen med døden eller i forhold til den.

Det finnes både Mor, Søstre, Bror, Barnet og Far til stede i de fleste diktene sammen med en rekke over- og underjordiske vesener (ånder, engler, døden) og ville dyr med en åpenbart symbolsk betydning. Søstre har hos Einan en spesiell stilling, men deres identitet er unnvikende, de forandrer egenskaper og attributt også innenfor ett dikt. Ved siden av dem dukker det opp dansere og danserinner, en dørselger, en fange og en narr. Dette mystiske kompaniet kan nesten minne om tarotsymboler fra den store arkana. Einan har selv sagt at dansere i hennes metaforiske univers symboliserer kjærester ${ }^{17}$ og dette er også framhevet i diktene. Narren synes til å indikere en diskursveksling, han setter ting i et annet perspektiv, undergraver det som skjer og retter fokus på noe annet enn det som leserne forventer som en logisk fortsettelse av diktet. Dørselgeren er i flere

13 Westerås, Lene E.: Ellen i luren. Ellen Einan i samtalen med Lene E. Westerås. In: Kuiper nr. 12005 , S. 64-66.

14 Vold, [op. cit. 9], S. 69-70.

15 Dragseth, Terje: Bortenfor det vi vet. In: Morgenbladet, 19.-25. 8. 2005, S. 42.

16 I Jorden har hvisket er det 29 ut av 55 dikt som innledes med «Jeg», i andre diktsamlinger er det sjeldnere.

17 Vold, [op. cit. 9], S. 70. 
tolkninger forenet med farsfigur. ${ }^{18}$ Men denne figuren er ikke så entydig heller. Det synes at dørselgeren først og fremst står for en luring som Einan selv antyder. ${ }^{19}$ Den siste av tilsynelatende menneskefigurer er fangen. ${ }^{20}$ Fangene bæres og finnes i nærheten av Jeget, men samtidig møtes de utenfor Jeget. Det er nesten umulig å si om fangene er en integrert del av Jeget, en slags ekstrakorporale med-identiteter, besjeling av våre synder som går hele tiden med, eller omvendt, om de står for vår fysiske kropp, det som binder oss til verden.

Det som kommer formelt ut av en undersøkelse av diktene, er at de kompositorisk sett ikke er så tilfeldige som de kan virke når vi følger Einans egne uttalelser. De er gjennomvevd av mange repetitive bilder, de er bundet sammen og svarer til hverandre. Likevel er mange trekk forvirrende, mange figurer gjentas med stor variasjon, de er ikke de samme på tvers av én diktsamling, for ikke å snakke om flere. Selve Mor som dukker opp i forskjellige kontekster, er i større grad ustabil og ugjennomsiktig. Er hun bra, en omsorgsfull mor som passer på sin barneflokk? Eller er hun ond, monstrøs og ubarmhjertig? Er hun levende eller $d ø d$ ? Eller dør og reinkarneres hun om og om igjen? Utstrekker tiden seg lineart i diktene eller er det en fragmentarisk tid hvor nåtid samtidig er alle fortider og alle framtider? Einans poesi er egentlig åpen for alle mulige fortolkninger, krystallklar og labyrintisk i det samme.

En annen egenskap som er typisk for Einans skrivemåte, gjør seg gjeldende på tvers av diktsamlingene - altså at hver diktsamling virker best i helhet, lest helhetlig som en stor diktmasse uten skarpe grenser mellom enkelte dikt. Tekstene innenfor en samling kommuniserer sammen og diktsamlingene står i dialog med hverandre. De komplementerer hverandre og skaper en slags diktmosaikk for leserne. Einan dyrker de samme emnene om og om igjen på tvers av hele dikterskapet. Man kan plukke utvalgte dikt og demonstrere den dikteriske helheten ut fra dem, de er nærmere dikt-representanter enn dikt-individer. De tilhører et lukket univers hvor alt skjer på andre premisser enn vi er vant til. Hennes diktunivers inneholder ikke «ledere» eller ikoniske dikt, alle diktene er små splinter av et magisk speil som speiler våre indre roms ansikt. Men likevel virker noen av diktene kraftigere enn andre, og det skjer særlig der hvor vi kan avlede meningen fra noe utenfor som $\mathrm{f}$. eks. kjærlighetsdiktene, diktene om den avdøde mora eller diktene problematiserende skrivingen og aldringen.

\section{Einan som modernist og surrealist}

Før jeg kommer til selve innholdsanalysen, vil jeg vise at Einans diktning kan føles beslektet med konkrete retninger, strømmer og bevegelser innenfor den europeiske mo-

18 Armstrong, Charles: Sacrifices of Ellen Einan. In: Scandinavian Studies 69, nr. 2 1997, S. 232-233.

19 Blant annet tenker hun på at man også kjøper fra dørselgeren det man ikke trenger. Men det er også noen som kan komme uventet og når som helst. Vold, [op. cit. 9], S. 71-72.

20 Etter mitt skjønn er fangen ikke behandlet i tekstene om Einans verk. Armstrong siterer verset «Jeg lever to sakte fangeliv» fra diktet «Bare å leve en gang» (109) og tolker det som Jegets splittelse $\mathrm{i}$ «Sacrifices» [op. cit. 18], S. 220. 
dernistiske tradisjonen. Jeg vil først og fremst bekrefte at Einan er en modernistisk dikter. Mange sier at Einans diktning høres arkaisk ut, kritikere peker stadig på dens ikke-klassifiserbarhet og unnvikende posisjon. Jeg mener tvert imot at Einans dikt er et eksepsjonelt bidrag til europeisk senmodernisme, og dette manifesterer seg på flere vis i diktene. For å bevise mine påstander vil jeg fremfor alt granske diktenes komposisjon. Men det er også diktenes dissonans og fragmentariske utsagn som understreker deres tilknytning til modernisme. Dessuten peker mye på at Einan tyr til surrealistiske strategier ved sin skriving. Om Einan er en surrealistisk dikter, er ansett forskjellig. For eksempel er Jan Erik Vold sterkt imot enhver begrensning, mens Øystein Rottem eller Hadle Oftedal Andersen ikke nøler når de nevner surrealisme ved siden av hennes navn. ${ }^{21}$ Einan er nevnt i surrealistiske tekstsamlinger, men denne tendensen oppfattes snarere som et hint for å betegne noen trekk ved hennes diktning. Uten tvil finnes det mange surrealistiske tegn i Einans diktning, og jeg vil her peke på noen av dem.

Et viktig trekk ved Einans poesi er at å finne en fast, stabil mening av diktene er enormt vanskelig. Flyktige øyeblikk av plutselig forståelse som forsvinner i det vi griper dem, er typiske for lesningen av Einans lyrikk. Vi kan gjenkjenne flere strategier som vanskeliggjør vår orientering i diktene. Noen av dem er rent språklige som sammensetningene som jeg kommer til å drøfte videre i teksten. Mange dikt virker også dialogiske med ofte repeterende «Ja» på begynnelsen av annenhver linje som i diktet «Er du vondt?» (133) hvor en uvanlig dialog foregår:

\section{[...]}

Jeg er fugl!

Ja, du er fugl.

Jeg er sørgeringen om din finger!

$\mathrm{Ja} !$

$[\ldots]$

En annen ting som virker veldig fristende for leserne, men som samtidig er ødeleggende for helhetsbildet de kan få ut av lesningen, er diktenes rastløshet. Hvis man vil sette ord på det som gjør diktene så fascinerende, men samtidig ubegripelige, kan man kanskje snakke om brudd $i$ tankene. Det er noe forstyrrende som fragmenterer tekstene, slike avvik i meningsforløpet som gjør språket så opakt. Det dukker opp tilsynelatende usammenhengende spørsmål plutselig, perspektiver snus eller Jeget begynner å snakke om noe helt irrelevant i forhold til resten av diktet. Slike brudd høres da ut som mystiske budskap som er tiltenkt bare for de innvidde, det er visdom som bare tilhører noen få utvalgte. For eksempel kan vi oppleve det når verset «Det er vann i mine krus.» fra «Er mor min her?» (225) er fulgt med «Døden leter opp sine.», og vi begynner å tenke om vann i krusene kan på en eller annen måte symbolisere kommende død.

21 Rottem, [op. cit. 6], S. 564 og Andersen, Hadle Oftedal: Poesiens pil: lyrikk 1959-. Oslo 1998, S. 174. 
Tankesprang, tradisjonsoppbrudd og mangel på faste former - alt dette er typiske kjennetegn ved modernistisk diktning. Per Olav Kaldestad og andre redaktører av boka Poetisk modernisme sier om modernismen i forordet:

Etablerte kontraktar blir stadig brotne, og nye kontraktar må stadig etablerast. Målet kan vera reint nedbrytande (dadaismen), oppbyggande (imagismen), eller både nedbrytande og oppbyggande (surrealismen) - men heile tida er oppbrotet eit grunnleggande utgangspunkt for poesien. ${ }^{22}$

Også Hugo Friedrich peker på det dissonantiske ved modernistiske dikt. Friedrich skrev en av de viktigste teoretiske verkene om europeisk moderne lyrikk og der understreker han de viktigste kjennetegnene ved moderne poesi. ${ }^{23}$ Han nevner særlig «tilbøjelighet til at være så fjernt som muligt fra formidling af et entydig indhold», og diktets evne til å virke som et mønster som egger både vår førrasjonelle bevissthet og vår fornuftstyrede nysgjerrighet. ${ }^{24}$ Videre skriver han:

Den dissonantiske spænding i det moderne digt viser sig også i anden henseende. Træk af arkaisk, mystisk, okkult herkomst kontrasterer med en skarp intellektualitet, enkel udtryksform med det komplicerede i udtrykket, sproglig færdigstøbthet med indholdsmæssig uafklarethed, nøjaktighed med absurditet, motivisk ubetydelighed med det heftigste udtryk. ${ }^{25}$

Friedrich finner flere spenninger på det formelle planet, men samtidig trer de også frem i innholdet. Virkelighet i de moderne diktene er frigjort fra de romlige, tidsmessige og sjelelige ordener. Friedrich definerer moderne lyrikk videre som fragmentarisk, konfus, typisk med sin sammenkobling av bilder. ${ }^{26}$ Han lager også ei ordliste med stikkord for modernisme: desorientering, oppløsning av det velkjente, den tapte orden, inkoherens, dyrkelse av det fragmentariske, ombyttelighet, antilyrisk poesi, ødeleggelsessyn, skjærende bilder, brutal plutselighet, astigmatisk synsmåte og fremmedgjørelse. ${ }^{27}$ Selv om vi sikkert kan finne både modernistiske og postmoderne trekk i dette forfatterskapet, viser mye av Einans skrivemåte en klar forbindelse med modernisme. Derfor har jeg også bestemt meg for å bruke videre begrepet modernisme om Einans diktning.

Einan er ikke bare den mest gåtefulle poeten i Norden, hun er sikkert den mest nyskapende poeten i Norge. Norsk lyrikk er forholdsvis fattig på avantgardistiske eksperimenter og språkleker. Ellen Einan står i spissen for en nytenkende og ukonvensjonell diktning. Allerede i Den gode engsøster møter vi en kraftig ekspansjon av sammensatte ordbilder: hudkornlyst, blodsjørose, skjøvetborthage, duggsøster, hudsøster, sørgepil, sфvnmarker,

22 Fosse, Jon, [et. al]: Poetisk modernisme. Oslo 1995, S. 8.

23 Friedrich, Hugo: Strukturen i moderne lyrik. Oversatt av Paul Nakskov. Danmark 1987.

24 Friedrich, [op. cit. 23], S. 8.

25 Friedrich, [op. cit. 23], S. 8.

26 Friedrich, [op. cit. 23], S. 13.

27 Friedrich, [op. cit. 23], S. 14. 
granskogsfangen. Sammensatte ord er slett ikke spesielle i vanlig norsk, norske poeter kan være veldig flinke i fantasifulle ordspill med dem, men Einan har klart å etablere et unikt, høyst selvrefererende ordforråd som ikke kan sammenlignes med noe annet. Vår søk etter mening kan ikke bli tilfredsstilt gjennom en vanlig metaforanalyse. Språket er kryptisk og unnvikende, som i første strofe fra «Ja, gode nattropet» (39-40):
Synden, lundens eneste glede,
mandeltrærnes taushet,
morsøyets døde hvithet,
søvnfanger, grå synderinne ved
mandelsøsters rosa hagetrær.

Ikke bare kompliserte sammensetninger, men også mange genitivkonstruksjoner hvor det sanselige ofte er knyttet sammen med det abstrakte, gjør tolkningen nesten umulig eller voldsomt utilfredsstillende. De fleste nye ordsammensetningene skapes i de tidlige diktsamlingene og etter Sene rop mellom bronsebergene blir verselinjene kortere, ofte dannet av bare ett ord. Men både i den tidlige og senere fasen er nominale ledd i overvekt og verbaler må vi ofte bare underforstå.

En hyppig bruk av metaforer laget ved hjelp av genitivkonstruksjoner kan generelt knyttes til surrealistisk diktning. ${ }^{28}$ Sånne konstruksjoner utfyller de fleste verselinjene og gjør språket til Einan til en slags religiøs allegori eller kultisk skrift. Genitivkonstruksjoner som «morsøyets døde hvithet», «ropets kilde» og «nattens mette munn» er også gode bevis på hennes referering til et stivt og konservativt riksmål. Språkformen som ligger langt fra Einans egen (og åpenbart sterk) ${ }^{29}$ dialekt fremmedgjør diktene fra det vanlige hverdagslivet og setter dem opp på en pidestall. Metafor i genitivkonstruksjon står i opposisjon til predikativ metafor, dvs. med kjernen i verbet (som i «sover i min hud»). Andrew Ortony sier i innføringsstudie Understanding metaphors at metaforer med genitiviske konstruksjoner muliggjør mer kryptiske ordbilder, ${ }^{30}$ noe som viser seg enda mer tydelig i Einans uvanlige ordbruk.

Også når vi ser på hvordan Einan produserer nye ord, finner vi kobling til surrealisme. Det er særlig Heming Gujord som har forsket på Einans nyskapninger. I artikkelen «Sovetreet med selvets krone duver» ${ }^{31}$ står Einans språkbruk i sentrum av hans interesse.

28 Zambor, Ján: Tvarovanie básne, tvarovanie zmyslu, Bratislava 2011, S. 38. Friedrich, [op. cit. 23 ], $210-211$. Friedrich knytter den genitiviske metaforen til modernisme og særlig Paul Eluard. Han peker på magisk sammenkobling av to helt fremmede ideer.

29 Samtiden-intervjuet er publisert som en ren transkripsjon av Einans dialekt.

30 «Genitive metaphors, for instance, seem to be richer in potential than predicative metaphors, perhaps because they leave so much more unsaid than do predicative metaphors. [...] However, in general one can expect much more complicated structures to play a role in genitive metaphors so that the solution to them may well depend on various other elements of the text as well as on extratextual factors. In such cases, understanding a metaphor may become something more like a problem-solving exercise.» I: Ortony, Andrew: Understanding metaphpors. Technical report no. 154. University of Illinois 1980, S. 18.

31 Gujord, Heming: «Sovetreet med selvets krone duver.» En tankegang i Ellen Einans tekstlandskap. In: Nordica Bergensia 11 1996, S. 171. 
Til tross for at Gujord finner veldig vanskelig å nøste opp meningstråder i diktene til Einan, avdekker han mye gjennom en grundig analyse av språkbruk og ordlaging. Einans dikting er preget av to ganske symptomatiske strategier. Disse strategiene er ikke bare vanskelige å forstå, men de er også vanskelige å oversette til mange andre språk. De er grunnen til både vår undring over diktene, men også til deres isolasjon. I første rekke merker vi at Einan «overbruker» nominale ledd på bekostning av verbaler.

Hos henne finner vi sjeldnere lange bildekjeder i normalsyntaks. Hun nøyer seg gjerne med å liste opp verbalfrie setningsemner som domineres av nominale ledd. Isolert sett kan slike kjeder se fullstendig meningsløse ut, men en slags mening kan framtre i lys av diktsamlingene (eller forfatterskapet) som helhet. ${ }^{32}$

Blant slike verbalfrie dikt finner vi imidlertid noen veldig resonerende og uforglemmelige stykker, for eksempel «Blodet og vennen» (262):

Blodet og vennen.

Det vakre bur - .

Det kalkede rom.

Enken,

Hennes lette jakke,

Arret, salven,

kroken på døren.

Ensomheten.

Døsige rom.

Lengselens dans,

venterommet.

Dette er en type dikt hvor handlingen ikke er fortalt fra Jegets perspektiv, og da er de vanligst komponert som en rekke veldige sanselige og eksperimentelle, upersonlige iakttakelser. Diktet virker ved første blikk som en blanding av tilfeldige nominale ledd, men når vi leser det til sammen, skaper beskrivelsene et bilde av enkens ensomme hus for oss. Selv om vi ikke finner noe verbal i hele diktet, hindrer det ikke språkets dynamikk og uttrykkskraft. Hver linje står for et separert bilde, men deres sammenblanding er veldig emotivt. Denne fragmentariske komposisjonen har sitt motstykke i den surrealistiske kropp-opplevelsen. Einans dikt er slike torso-dikt, skisser eller kollasjer av poetiske bilder som til sammen fører til et usedvanlig bilde av verden. Slike beskrivende dikt finnes oftere i den senere delen av forfatterskapet. 
Men Gujord går enda dypere i sin analyse og ser nærmere på den semantiske betydningen av enkelte ledd i nominalfraser. Han får øye på et klart mønster innenfor Einans hyppige bruk av sammensetninger. Einan skaper sine bilder på to måter. Hun kombinerer enten to kontrastive ledd - et abstrakt og et konkret (søvnhage) - eller to konkrete ledd (blodrøttene). Det abstrakte i kombinasjon med det konkrete skaper en svært poetisk spenning og får oss til å tvile på meningen. Men det er verdt å merke seg at Einan plukker forledd og etterledd fra et begrenset og repeterende antall ord og betegnelser. Gujord kaller denne teknikken «montasje» i samsvar med Theodor Adornos teori om surrealisme. Adorno sammenligner videre surrealistiske «monterte» bilder med fetisjer der enkelte elementer i kollasjer stivner i en helt fremmed kontekst. Her finnes det en analogi mellom tidlige surrealistenes metode og Einans formspråk. Einan «klipper ordene løs fra deres normalspråklige betydningsområder og setter [monterer] dem inn i nye og usette sammenhenger». ${ }^{33}$ Disse surrealistiske sammensetninger kan nesten minne om norrøne kjenninger, for Einans metaforer får nærmere en fast form. Samtidig er det nettopp substitusjonsprinsippet med sine begrensninger som gjør Einans dikt så forskjellige fra «ekte» surrealistiske automatiske dikt som i for eksempel Les champes magnetiques. Einans univers virker mye mer gjennomtenkt, verden hun presenterer, har faste rammer og alt kretser rundt det samme emnet. Selv om vi kan finne det vanskelig å tolke diktene, føler vi en slags hemmelig innebygd struktur i måten handlingene utspiller seg på i et åpenbart ruralt miljø med nesten mystisk stemning. Surrealistiske tekster skrevet ved hjelp av automatteknikken er preget av ukonvensjonelle møter av enkelte objekter, irrasjonalitet knyttet til moderne samfunn.

Vi kan ikke betrakte Einan som en «ortodoks» surrealist, men vi kan finne både de mer tydelige og de skjulte surrealistiske og surrealiserende kjennetegnene i hennes lyrikk. Det finnes selvfølgelig flere forskjeller mellom den bretonske surrealismen og surrealismen i de neste tiårene. Men siden Breton opplevde surrealismen både som en levemåte tilgjengelig for alle og en tidsbestemt politisk, revolusjonær bevegelse, kan vi alltid tilegne oss den på nytt. ${ }^{34}$ Surrealismen er egentlig en måte å bruke språket på, det er nærmest en innebygd egenskap ved språket, og vi må bare vekke den til live. En slovakisk litteraturforsker, Ján Zambor, har laget en omfattende definisjon av en poetisk metafor i sin bok Tuarovanie básne, tvarovanie zmyslu. ${ }^{55}$ Her definerer han en surrealistisk metafor som en spesiell type av metafor som står litt for seg selv. Den er basert på avstandsforhold - en empirisk og logisk inkompatibilitet av beskrevne fenomener, deres irrasjonalitet, drømmeri, spådom, hallusinatorisk virkning og brutalitet. Den surrealistiske metaforen imiterer ikke virkeligheten, tvert imot søker den etter «gjemte analogier». Den forener vår sensuelle fornemmelse, forløser fysiske og empiriske erfaringer. Hvis vår sanseoppfatning er helt oppløst, kan surrealistene lage ordbilder bygget på en «forandret virkelighet» som går utover vår vanlige virkelighetsramme. Ut av dette er det klart

33 Gujord [op. cit. 31], S. 185.

34 Se Første surrealistiske manifest. In: Fløgstad, Kjartan [et al.]: Surrealisme: en antologi. Oslo 1980. Oversatt av Solveig Schult Ulriksen.

35 Zambor [op. cit. 28], S. 38. 
at Einan skaper sine ordbilder ifølge de samme reglene som de surrealistiske metaforene ble skapt etter.

\section{Lekenhet og ondskap i lys av surrealisme}

Surrealistiske metaforer hos Einan utspiller seg på flere plan. Det nyskapende språket hennes er ekstra understreket av de ovennevnte innovative sammensatte ordene, men vi kan tenke oss at slike nyskapninger også dannes på et setningsnivå og ikke bare på et ordnivå. Emnemessig sett har surrealistene vært opptatt av flere spesifikke motiver. Som jeg har antydet, står selve skapeaktiviteten i sentrum av surrealistisk forskning. Surrealistene liker dessuten de mest ambivalente og kontroversielle temaene. Søvn og dens tvetydighet er både kilden til drømmebilder og en motivisk inspirasjon. Historisk sett har søvnbilder vært forbundet med døden, men også med fascinerende visjoner. I Einans lyrikk er søvn legemliggjort i Bror Søvn, men den lever også i søvnfugler, søvnhager og særlig valmuer. Valmuen er en av de mest konvensjonelle symboler på søvn, som i det eponymiske diktet «Valmuen» (206):

En kort og lett ondskap.

En lys og fast nattfugl.

Derfor er vi svale, sa duene,

lekte svarets lek.

Jeg leker murens første lek, sa gode du,

var en klok vokter,

satt i valmuens krone,

lyttet.

Kompositorisk sett er diktet ganske enkelt, men det har modernistiske preg og tar utgangspunkt i tilstandene som sto i kjernen av surrealistisk interesse. Duene våkner etter valmuens rus. «En kort og lett ondskap» kan representere en kort lur, en tilstand som ligger på grensen mellom drømmen, virkeligheten og galskapen. Å leke «svarets lek»kan peke på denne opplevelsen når man er ute av seg, nesten $\mathrm{d} \varnothing \mathrm{d}$, når døden og søvnen sammenstilles. Hele diktningen til Einan er konsentrert rundt leting etter svarene, og at de kun kommer etter døden, angir Einan flere steder. ${ }^{36}$ Å dope seg er å komme nærmere døden og dermed også til svarene. Døden som et forløsende element som kan nærme oss visdommen, er et tema typisk for store esoteriske lærer, og Einan har selv uttalt seg flere ganger at hun var opptatt av gnostisismen som også gjenspeiles i diktene.

Ved siden av drømmen, søvnen og underbevisstheten dyrket surrealismen også andre motiver. Et av dem var barndommens fantasi og dens ubegrensede kraft. Barndommen hadde egentlig ganske lik status som drømmetilstander. Den nærmet seg livets ubegripe-

36 Den første verselinjen i «Etter døden?» (194) er: «Jeg skal være hos svarene når de kommer.» 
lige mirakler. På en måte kunne en surrealistisk kunstner/dikter «gjenvinne» barndommens muligheter med surrealisme - ved hjelp av forskjellige leker, ordspill og psykisk automatisme. Et godt eksempel på surrealistenes lekenhet er Cadavre Exquis, et bilde- og eventuelt ordspill med tilfeldighet og absurditet. Også Maurice Blanchot definerer tre skapeprinsipper i surrealismen som lek, tilfeldighet (uforutsigbarhet) og møte. ${ }^{37} \mathrm{Hos}$ Einan framkaller forskjellige leker (svarets lek, murens første lek) barndommens erindringer, men samtidig peker de på noe forbudt eller hemmelig. I tillegg er leker ofte knyttet til nettopp søvn, som også i «Jeg var foran barnet» (199): «Jeg ble dratt ut i søvnhagen, der de lekte med føll og små lønndomsskrin.» Her betegner lek og søvn en før-fødsel-tilstand. Jeget burde fødes om og derfor er det dratt til søvnhagen som representerer en slags mellomtilstand eller mellomeksistens.

I motsetning til barndommen kultiverte surrealistene nettopp dødstematikken. «Surrealismen innfører Dem i døden som er et hemmelig forbund. Den skal behanske Deres hånd og begrave det dype $\mathrm{M}$ som ordet Minne begynner med,» står det i manifestet. ${ }^{38}$ Her peker Breton særlig på glemselen som den største fordelen ved døden (vs. Einans «jeg hadde den første hagen glemt»). Men det er også det komiske og det absurde ved døden som surrealistene trekker fram. Breton skriver «Så vakker en død// Hvor du må le der alene», eller Philippe Soupault fabulerer i minnedikt til Tristan Tzara: «Vi lo godt da vi hørte du var død/ Vi var redde for at du var evig». ${ }^{39}$ Også surrealistene utvikler den arkaiske tanken hvor drømmen er sammenkoblet med døden som for eksempel brødrene Hypnos og Thanatos i gresk mytologi. «Og om du dør, er du så ikke sikker på å våkne opp blant de døde?» spør Breton i Første surrealistiske manifestet.

Einan framstiller døden som et «levende» vesen, den er personifisert i en menneskelig figur. Døden er ofte den tredje angelen i søvn-lek-trekanten. I «Jeg var foran barnet» (199) skriver hun videre: «Døden skar opp huden sin./ Jeg så hans veldige hage derinne.» Døden har til og med hud, er vakker, kommer på besøk, kan møtes. Den fysiske nærheten til døden blant de levende kan vekke bekymring - hos både lesere og Jeget. Jeget vet ikke selv hvilken stilling det skal ta. I den mest eskalerte innrømmelsen er Einan modig nok til å erklære at vi kan «elske døden» i diktet «Jeg føres bort» (176). Det er en utfordring å leve med døden som en uatskillelig del av oss selv. I slike momenter når døden blir til vår venn eller bekjente, påstår Einan egentlig at livet er en absurd, umulig tilstand, dets største motsetning er dets absolutte avslutning. I det ovennevnte diktet minner døden om løk. I egyptisk mytologi var løken et symbol på det evige livet. Dens åpne og sirkulære form illuderer tanker på uendelighet - også hos Einan kan vi anta at døden er ansett som en port til vår neste inkarnasjon.

37 Blanchot, Maurice: The infinite conversation. Oversatt av Susan Hanson. Minneapolis 1993, S. 421.

38 Fløgstad [op. cit. 34], S. 110.

39 Diktene oversatt av Sissel Lie. Finnes i: Fløgstad [op. cit. 34], S. 78 og 76. 


\section{Skjønnhet som skremmer}

Når man vil avsløre noe av Einans hemmelighetsfulle diktning, må man leke med ordenes utallige betydninger. Diktenes budskap balanserer på grensen mellom en bekymringsløs lekenhet og noe bekymringsfullt og fatalt. Ordlekene og den surrealistisk lekende imaginasjonen er bare en side av Einans poetikk. Den ekte karakteren av diktningen ligger egentlig i mye mørkere påstander. La oss se på diktet «Ånei, jeg ønsker ingen vakker prins» (151):
Ånei, jeg ønsker ingen vakker prins.
Jeg ønsker vakre små lyngalver
og blodrop fra uren
og valmuens blodfarge
og syndens faste hånd.

Valmuens blodige rødhet, som er påpekt i dette korte diktet, kan ikke klart kobles med søvnsymbolikken eller innvielsen. Det ligger noe farlig og samtidig tiltrekkende bak ordene. Den iøynefallende blodmetaforikken som Einan utvikler på tvers av dikterskapet, er ikke et uttrykk for bot eller skam. Blodfarge og syndenes hånd framkaller en erotisk fornemmelse Jeget lengter etter. Jeget venter utålmodig på synden.

For at Jeget er tiltrukket til noe skremmende eller voldelig, har også surrealistene funnet utrykk til. Deres påfunn av begjersobjekt og konvulsivisk skjønnhet ${ }^{40}$ har sine røtter i Bretons forvrengte forståelse av medisinske, psykiatriske begrep og tilstander han har møtt som assistent på en nevrologisk-psykiatrisk klinikk. Breton har blitt fascinert av hysteriets estetikk og Freuds tanker om det uhyggelige (Das Unheimliche). ${ }^{41}$ Han finner en eksepsjonell skjønnhet i ekle og urovekkende glimter, men også i det sjokkerende og traumatiserende. I hans forståelse av skjønnhet kobles begjær og seksuell angst sammen. Og konvulsivisk skjønnhet er et resultat av surrealistenes skjønnhetsutforskningsprosjekt. I Nadja skriver Breton: «Convulsive beauty will be veiled-erotic, stationary-detonating and circumstantial-magical or will not be at all.» ${ }^{42}$ Det er skjønnhet fylt av motsetninger, den kan finnes i tilfeldige objekter, og den må vekke begjær hos poeten. Den skal ikke bare sjokkere, men den kan også «unlock the rich repertoire of imagery located in the depths of the unconscious». ${ }^{43}$ Her kan vi trekke tråder fra begjæret til poesien. Poesien er i surrealistisk forstand en ren transkripsjon av vårt begjær. Og ved hjelp av hallusinasjoner, drømmetolkning, automatskrift og galskap kunne vi utløse dette begjæret, skjønt det av og til var obskurt og perverst.

40 For å utforske mer om dette begrepet, se: Foster, Hal: Compulsive beauty. Cambridge 1993.

41 Freud, Sigmund: Det uhyggelige. Oversatt av Hans Christian Fink. København 1998.

42 Picon, Gaëtan: Surrealists and surrealism. Geneva 1977, S. 132.

43 Tythacott, Luise: A 'Convulsive Beauty': Surrealism, Oceania and African Art. In: Journal of Museum Ethnography 11, 1999, S. 43. 
Surrealistene bryter med den langvarige estetiske skjønnhetstradisjonen på dette punktet. Breton holder på å løse skjønnheten fra de estetiske rammene. Han er mer opptatt av det følelsesmessige. Den konvulsiviske skjønnheten knytter seg ofte til kroppen og seksualiteten. Den er høyst urovekkende, voldelig, obskøn, disruptiv, men samtidig fantastisk og mysteriøs. Beskrivelsene fylte med kadavre, torturutstyr og andre ekstremt smertelige handlinger var veldig typiske for en del både mannlige og kvinnelige surrealister. Tsjekkiske surrealister parterte og fragmenterte menneskekropper for å lage kollasjer og montasjer. I samsvar med surrealistiske tanker om begjærsobjekter og konvulsivisk skjønnhet utviklet de en typisk ikonografi på 1930-tallet. Grafiske blader de tsjekkiske surrealistene lagde, ble fylt av fragmenterte bryst, torsoer eller lepper som ofte sto på grensen til pornografi. Lignende strategier brukte ikke bare billedkunstnere, men også poeter i sine framstillinger av mennesker. I sin studie om kropp i tsjekkisk surrealisme overtar Vojvodík tesen om at surrealismen generelt hovedsakelig problematiserte kropp-tid-romstrukturer. ${ }^{44}$ Han peker også på at kroppen hos de tsjekkiske surrealistene er knekket, revet i stykker og nærmest er presentert som «kroppsøyer». ${ }^{45} \mathrm{Ut}$ av dette finner vi to motstridende strategier som omarbeider kropp og omverden hos Einan. Kroppen er både adskilt og fiksert på et begrenset Jeg med sin hud, munn, sår; og samtidig er den dispergert i en «oseanisk» opplevelse av seg selv og omverden hvor Jeget synes til å innlemme hager, rom og andre vesener.

Vi kan finne spor av begge tendensene i den surrealistiske kroppsomarbeidelsen i Einans diktning. For det første møter vi allerede i den første diktsamlingen «hugget gren», det billedlige navnet på Jeget, men også en fragmentarisk tre-kropp. Det gjentas flere steder i alle diktsamlingene. ${ }^{46}$ Den huggede grenen er både en torso og et lem. Den er adskilt og revet fra sin rest. Kanskje ikke fra resten av seg selv, men fra andre, fra hele det menneskelige selskapet. I et annet dikt, «Jeg sover ute» (172) skildrer Einan et trøstesløst miljø: med kjøttetende planter, vakre, men døde hester inne i muren og det indre mørket: «Så kjører jeg mørk hugget gren ut av hagen./ Skadd, funnet, forandret og brutt./ Så sover jeg tom.» Vi kan ikke sikkert påstå at Jeget og grenen er det samme i dette tilfellet. Er dette en sår og bitter hulk over sitt eget liv? Kanskje hører grenen til gråteskogen fra diktet «Jordens faste farge og de blide munner er her» (175). Hugget gren er samtidig et stabilt element, den kommer igjen og igjen selv om andre vesener og bilder forandres. Men heller ikke grenen er uforanderlig. «Jeg var av hugget gren [...] en sten er jeg nu» hevder Jeget i «Er gude du en sten» (193). Grenen forblir forsteinet etter å bli brutt og skadet. Som grenen var Jeget hugget, skadd, brutt, men forble den handlende og følende i motsetning til steinen. ${ }^{47}$ Hugging er også beskrevet som en spesifikk prosess, snarest barneadskillelse fra morsfiguren. I det dunkle diktet «Mitt landskap» (230) overtar Jeget

44 Her pekes det særlig mot Heideggers hermeneutikk, Merleau-Pontys fenomenologi og Lotmans antropomorfisme. Vojvodík, Josef: Imagines corporis. Tělo v české moderně a avantgardě. Praha 2006, S. 29-31.

45 Vojvodík, [fotnote 44], S. 34.

46 Den aller første diktet i Den gode engsøster begynner med «Jeg er en hugget gren./ Vår mor trakk meg bort fra/ ørnens ville flukt.» (31)

47 Det stilles egentlig et spřrsmíl: «Er du en fřlsom sten?» Og svaret etterlater oss tvil: «Jeg er hva jeg er. Dřr snart, sí er jeg glemt.» 
søsters stilling: «En søster bæres i hus./ Da er dette landskapet mitt./ Våre hagetrær hugges./ Da er det mor min som svinger øksen.» I forbindelsen med hugget gren er også $\varnothing \mathrm{ksen}$ et viktig symbol. Øksen er farlig og skadelig, den skjærer og gjennomtrenger overflater. Den nevnes både i begynnelsen og slutten av grenens eksistens.

For det andre gir Einans lyriske Jeg uttrykk for det perverse ønske - om å bli slaktet, forenet med dyr. Særlig i diktsamlingen Sene rop mellom bronsebergene finner vi flere urovekkende beskrivelser av voldelige handlinger, bønn om å bli skadet, slaktet, brent eller til og med muret inne. Vi står foran svært kroppsbaserte og drastiske ønsker - noen ganger minner de om en dyrisk essens av Jeget, noen ganger passer handlingene mer for mennesker. Er dette snakk om seksualfantasier eller snarere om en form for innvielse? Det er umulig å hevde sikkert at Jeget begjærer noe seksuelt, for i Einans lyrikk virker alt kroppslig som en gjenspeiling av dype sjelelige fornemmelser. Er dette da et uttrykk for absolutt kjærlighet? Det er heller ikke klart om vi snakker om mellommenneskelig kjærlighet eller om en slags overjordisk overgivelse. Einans religion er uklar, men vi kan finne spor på en panteistisk opplevelse av Gud og naturen med far, engler, ånder, øverste mor som alle forholder seg til, og hager som kan forstås som både indre og ytre rom.

Ønsket om å la seg såre uttrykker Einan svært tidlig i sin poesi, til tross for at det ikke er erklært helt fra den aller første diktsamlingen. Men det at Jeget har overlevd døden, hevder hun allerede i den privatutgitte diktsamlingen («Jeg brant ned og er en vill ånd»). I diktet «Jeg lengter III» (130) er det morskikkelsen som skal foreta en drapshandling istedenfor å hugge grener skal hun brenne Jeget etter dets ønske:

Jeg vil skades av mulden og vekstene,

lytte til markens fine snakk,

men jeg vil brennes av husets vektløse mor,

det vet jeg.

I et annet dikt er Jeget en drikk som skal settes i glasset (og deretter drikkes) og en snefugl som skal jaktes. Enda mer gjennomtenkt tortur beskriver Jeget $\mathrm{i}$ «Bær meg til slakteren» (245):

Bær meg til slakteren.

Elsk meg.

Jeg er dyret.

Jeg løfter ikke mine øyne mot bergene.

Meg hadde de båret ut til ensomhetens blodige stall.

Der la de slektens munn mot hjertet mitt,

drakk mitt blod,

åt mine sår.

I Sene rop mellom bronsebergene virker Jeget helt febrilsk. Særlig her nærmer Einan seg den mystiske talen typisk for barokkens katolske lyrikk. Men samtidig bryter hun med dette 
når hun forener Jeget med et dyr. Dette bibelske forbildet er mye eldre enn barokkens mystikk og peker mot Abrahams offerlam. Også Jesus betegnes som offerlammet. Men vi kan ikke engang si om det er et lam eller et føll som ofres. Det er ikke bare Jeget som er såret, men Jeget sårer også. Det sier «Jeg er ond.» eller «Ja la kalde skoger øde». Samtidig ber Jeget om kjærlighet oftere enn før. Men å bli elsket betyr ofte å nærme seg noe farlig: «Elske./ Døsig la seg falle./ Men onde toner er her...».

\section{Subtile paralleller}

Takket være denne selvskadende tendensen går Einan litt utover den vanlige surrealistiske rammen, men paradoksalt nok finner vi en samklang med en gruppe surrealister som har blitt tilsidesatt fra surrealismens annaler. I boka Kvinners surrealisme: Hyener og nattsommerfugler påstår Sissel Lie at kvinner alltid har stått litt på kanten av den surrealistiske bevegelsen, og at de har tatt opp spesifikke emner i sine kunst- og forfatterskap. Ifølge Lie dyrker kvinnersurrealister identitet som det sentrale punktet i sine prosjekt. Og i skildringer av denne identiteten går de enda videre og finner de enda skarpere bilder enn de mannlige surrealistene. Her sikter jeg særlig til den franske poeten Joyce Mansour. Hun var av jødisk-engelsk opphav, men oppvokst i Egypt, og som voksen flyttet hun til Frankrike. Der kom hun i kontakt med Breton og fulgte surrealistene. Et typisk trekk ved Mansours dikt er sadomasokistiske erotiske motiver og et veldig ambivalent forhold til moderskap. Samtidig er hennes truende kvinnebilde skapt i samsvar med surrealistenes kneler-kvinnebilde, deres forestilling om den farlige og ødeleggende kvinnen. Vi kan se på diktet «Inviter meg...»: ${ }^{48}$
Inviter meg til en natt i din munn
Fortell meg om elvenes ungdom
Trykk min tunge mot ditt øye av glass
Gi meg ditt ben som amme
Så skal vi sove bror av min bror
For kyssene dør fortere enn natten

Hos Mansour blander det absurde seg med det forbudte, hun utforsker på en måte grenser av vår imaginasjon, vårt natteansikt. «Mannen som jeg dreper mannen som jeg fornekter» skriver hun et annet sted..$^{49}$ Hun både skader menn (kastrasjon er også ett av motivene hun bruker) og lar seg skade («for å dø lykkelig/ mellom de råtne kanintennene» ${ }^{50}$. Diktningen hennes var ellers inspirert av både antikk og egyptisk mytologi, og motiver av kvinnelig guddommelighet var ikke fremmede for henne heller.

\footnotetext{
48 Lie, Sissel og Gundersen, Karen: Kvinner i surrealisme. Lysaker 1978, S. 71. Lies egen oversettelse.

49 Lie, Sissel: Kvinners surrealisme: Hyener og nattsommerfugler. Trondheim 2011, S. 144. Alle dikt i Lies egen oversettelse.

50 Lie [op. cit. 49], S. 144.
} 
Mansour er i beskrivelsene sine mye mer brutal og voldelig enn Einan, men uansett er disse to dikterne sammenlignbare. I samsvar med modernismen går også Einan mye på det kroppslige. Kroppens overflate - huden - er et sted for eksperimenter, for skade, vekst, metamorfose. Når Lie sier om Mansour at en del av hennes litterære program er «å trenge inn i det ubevisstes hemmeligheter gjennom diktningen og treffe noe i leserens hemmelige rom gjennom sitt identitetsarbeid $»^{51}$, er hun ikke langt fra Einans "program». Diktet «Jeg farger deg ukuelig blå» (195) høres slik ut:

Jeg farger deg ukuelig blå,

min huds avkledte.

Så gjør jeg pyramider i sand,

og skaper deg et løst lite hudrom

i døden.

Når vi ser på diktet isolert fra resten av Einans forfatterskap og i relasjon til samtidig internasjonal diktning, kan vi nesten ikke skille den fra andre modernistiske dikt hvor den surrealistiske imaginasjonen gjør seg gjeldende. Hennes dikt minner om trylleformular med sin karakteristiske rytme og blanding av foreldet språk med nyskapninger. Min huds avkledte har en utydelig identitet - er han Jeget eller er han adskilt fra Jeget? Huden er av stor betydning i Einans diktning. Huden representerer noe somatisk, den minner oss om vår kroppslige eksistens i den fysiske verden, og den gjør fysisk kontakt mulig. Huden «kler oss», den er den ytre grensen av vårt korporlige Jeg. Å kle seg av huden symboliserer dermed noe veldig intimt. Den som er hudavkledt, er ikke bare naken, men også åpen og sårbar. Og dette åpne og hudløse farges ukuelig blå. Det eiendommelige «min» som vektlegger eierforholdet mellom Jeget og den avkledte, peker litt i retning av det som farges blå er en del av Jeget - et barn eller en annen slektning. Blå farge er i flere religioner knyttet til det himmelske og sakrale, også i egyptisk mytologi. ${ }^{52}$ Pyramider i sand er ikke et vanlig bilde i Einans diktning, men i denne sammenheng gir de mening. Her er det altså mest sannsynlig snakk om en slags «mumifikasjon», Jeget begraver sin huds avkledte i sandpyramider, på et sted hvor døden demonstrerer sin makt og vil for alltid minne oss om de avdøde.

Einans automatiske skriveteknikk kan sammenstilles den surrealistiske automatismen. Mens automatismen veldig snart ble «utmattet» for de mannlige surrealistene, opplevde Mansour noe lignende hver gang hun satt pennen på papirarket. Hun sammenlignet sitt forfatterskap med tortur - det å skrive er å skrike ut det sårende. Lie sammenligner dette med en slags terapi. Videre skriver hun: «Ved å karakterisere diktene som skrik og seg selv som kropp som skriker, gjør Mansour seg til et medium for det ubevisste. $»^{53}$ Mansour var bevisst over sin forfatterevne, men hun innrømmet at hun ikke hadde bearbei-

51 Lie [op. cit. 49], S. 158.

52 Ancient Egypt: The Mythology. Colors. http://www.egyptianmyths.net/colors.htm (13. 3. 2017).

53 Lie [op. cit. 49], S. 154. 
det sine dikt. ${ }^{54}$ Andre teoretikere har beskrevet hennes skriveprosess med enda skarpere ord - som en form for galskap. Stéphanie Caron kaller Mansours skrivemåte for «parole compulsive», altså tvangstale. ${ }^{55}$ Denne korte parallellføringen trekker fram et kjennetegn som Einan og Mansour har til felles. Lie har påpekt at selvbildet er kvinnesurrealistenes hovedtema. De bearbeider erfaringer som er knyttet til kvinnekroppen: abort, fødsel, amming og aldring. ${ }^{56}$ Disse impulsene ble senere mottatt av feministiske kunstnere, men de har utforsket dem på et mindre hallusinatorisk og svermerisk vis. Også den dunkle, dekadente underbevisstheten og alle mørke drifter knyttet til dikterens fantasi får plass hos i begge forfatterskap. I forhold til dette kan vi spørre oss om det definitive bildet Einan søker i sine dikt, ikke er sitt kvinnelige forbilde - et absolutt, idealisert bilde av seg selv som både en mor, en datter og en aldrende kvinne.

\section{Oppsummering}

I denne artikkelen har jeg presentert Einans diktning og har framhevet de mest typiske trekkene som kjennetegner hennes poetiske univers. Siden den første diktsamlingen har hun skapt en fascinerende verden med mange høyst uvanlige poetiske bilder. Mye av hennes symbolske beskrivelser peker til noe arkaisk, men når vi ser på enkelte forfatterstrategier i detalj, kan vi lese henne som en modernistisk dikter. Spenningen i diktene skapes ved hjelp av tankesprang, distrahering og mangel på faste former, og nettopp disse egenskapene forsterker hennes utgangspunkt som modernist. Einans vokabular er dessuten utrolig nyskapende. Hun benytter seg av genitiviske metaforer og det som Heming Gujord definerer som Adornos «montasjeprinsipp». Begge tendensene er veldig vanlige for surrealistisk diktning.

I den andre delen av artikkelen har jeg utelukkende lagt vekt på kjennetegnene som knytter Einan til den surrealistiske bevegelsen. Det er absolutt legitimt å snakke om en surrealistisk symbolikk og bildebruk i Einans tilfelle. Det aller synligste skjæringspunktet mellom Einan og surrealismen er den psykiske automatismen som har vært hennes eksklusive skriveteknikk, men det finnes også andre viktige kjennemerker. Det er synlig i mange innholdsmessige paralleller at de einanske diktene har den samme forløsende energien som den avantgardistiske strømningen hadde. Selv om vi politisk sett neppe kan betrakte henne som surrealist, har hun dyrket og utvidet det surrealistiske språket. Einans språk er eksepsjonelt vakkert, fangende og rikt på poetiske bilder, men i det samme unnviker diktene ikke beskrivelser av skadelig kjærlighet, selvoppofrelse og håpløs lidelse. Typiske surrealistiske motiver som et ambivalent forhold til døden, begrepet konvulsivisk skjønnhet, drømmegranskning og lek med ord og språk er bearbeidet i Einans forfatterskap hvor søvn, drøm, død og forveksling er noen av hovedmotivene. Et enda tettere forhold finner vi mellom Einan og Joyce Mansours poesi, hvor også det

54 Lie [op. cit. 49], S. 156.

55 Caron, Stéphanie: Réinventer le lyrisme. Le Surréalisme de Joyce Mansour. Genéve 2007, S. 13.

56 Lie [op. cit. 49], S. 36. 
spesifikt kvinnelige kommer til uttrykk. Selv om man ikke helt kan knytte sammen disse dikterne med svært forskjellig bakgrunn og skrivestil, er tyngdepunktene deres stor sett like - det er moderskap, ødeleggende og masochistisk kjærlighet og mytologi. Dessuten sammenligner begge to skrivingen med et påtrengende og spontant behov som ikke kan forklares.

\section{Bibliografi:}

ANDERSEN, Hadle Oftedal (1998): Poesiens pil: lyrikk 1959-. Oslo.

ARMSTRONG, Charles I. (1997): The Sacrifices of Ellen Einan. I: Scandinavian Studies 69 (2): $212-42$.

ARMSTRONG, Charles I. (2017): «Jeg er en hugget gren». Fra tap til fravær i Ellen Einans forfatterskap. ' I: HAMM, Christine, Siri Hempel LINDØE og Bjarne MARKUSSEN: Lidelsens estetikk. Sår, sorg og smerte i litteratur, film og medier. Bergen, S. 27-52.

BLANCHOT, Maurice (1993): The infinite conversation. Minneapolis.

CARON, Stéphanie (2007): Réinventer le lyrisme. Le Surréalisme de Joyce Mansour. Genéve.

DRAGSETH, Terje (2005): Bortenfor det vi vet. I: Morgenbladet, 19.-25. 8., S. 42.

EINAN, Ellen (2011): Samlede dikt. Oslo.

FLØGSTAD, Kjartan [et al.] (1980): Surrealisme: en antologi. Oslo.

FOSSE, Jon, [et. al] (1995): Poetisk modernisme. Oslo.

FOSTER, Hal (1993): Compulsive beauty. Cambridge.

FREUD, Sigmund (1998): Det uhyggelige. København.

GUJORD, Heming (1996): «Sovetreet med selvets krone duver.» En tankegang i Ellen Einans tekstlandskap'. I: Nordica Bergensia 11, S. 171.

JOHANSEN, Hugo (2012): En gåtefull verden. In: Lofotposten, 15. 5. 2012, S. 12.

LIE, Sissel og Karen GUNDERSEN (1978): Kvinner $i$ surrealisme. Lysaker.

LIE, Sissel (2011): Kvinners surrealisme: Hyener og nattsommerfugler. Trondheim.

ORTONY, Andrew (1980): Understanding metaphpors. Technical report no. 154. University of Illinois.

PICON, Gaëtan (1997): Surrealists and surrealism. Geneva.

ROTTEM, Øystein (1998): Etterkrigslitteraturen. Bind 3: Vår egen tid 1980-1998. Oslo.

STRAUME, Eilif (1995): I Ellen Einans forunderlige have. I: Aftenposten. 26. 1. 1995.

TYTHACOTT, Luise (1999): A “Convulsive Beauty': Surrealism, Oceania and African Art. I: Journal of Museum Ethnography 11, S. 43.

VOLD, Jan Erik (1990): Poetisk praksis 1975-1990. Oslo.

VOLD, Jan Erik (1985). Jeg som bare lener blyanten sånn passe mot papiret og la den fly.... I: Samtiden 1, S. 65-72.

VOJVODÍK, Josef (2006): Imagines corporis. Tělo v české moderně a avantgardě. Praha.

WESTERÅS, Lene E. (2005): Ellen i luren. Ellen Einan i samtalen med Lene E. Westerås. I: Kuiper nr. 1 2005, S. 64-66

YSTAD, Vigdis: Diktet. I: Dag og tid, 12. 1. 2018.

ZAMBOR, Ján (2011): Tuarovanie básne, tvarovanie zmyslu, Bratislava.

Lyrikeren Ellen Einan priset. I: Aftenposten, 22. 8. 2002.

Ancient Egypt: The Mythology. Colors. http://www.egyptianmyths.net/colors.htm (13. 3. 2017). 
Mgr. et Mgr. Eva Pitronová / 361808@mail.muni.cz

Masarykova univerzita, Filozofická fakulta

Ústav germanistiky, nordistiky a nederlandistiky

Arna Nováka 1, 60200 Brno, CZ 
